http://dx.doi.org/10.12775/szhf.2015.007

Anna Tomaszewska

UNIWERSYTET JAGIELLOŃSKI, KRAKóW

\title{
Poznanie naoczne w filozofii Kanta według Benedykta Bornsteina
}

Jeden ze współczesnych problemów w interpretacji Kanta sprowadza się do pytania, czy Kantowska koncepcja doświadczenia stanowi wersję konceptualizmu, czy też jest ona bliższa jego przeciwieństwu, jakim jest non-konceptualizm. Konceptualizm w sprawie treści doświadczenia percepcyjnego głosi, że treść ta ma z konieczności charakter pojęciowy (skonceptualizowany). Przeciwieństwo tego poglądu oznacza negację tej tezy. Treść rozumie się tutaj po Frege’owsku, tzn. jako sposób reprezentacji, odniesienia umysłu do przedmiotu. Zgodnie $\mathrm{z}$ założeniem przyjmowanym w debacie między konceptualizmem a non-konceptualizmem odniesienie to można scharakteryzować dzięki rozróżnieniu na akt, przedmiot i treść przedstawienia, znanemu w polskiej filozofii z prac Kazimierza Twardowskiego ${ }^{1}$.

Wspomniana debata porusza istotne problemy teorii poznania i filozofii umysłu, dyscyplin filozoficznych, w których Kant zajmuje niekwestionowaną pozycję. Stawia ona bowiem takie pytania: Czy treść percepcji może być dana bez pośrednictwa pojęć? Czy treść dana w taki sposób może odgrywać istotną rolę nie tylko $\mathrm{w}$ nabywaniu, ale także w uzasadnianiu przekonań empirycznych? Czy posiadanie pojęć jest koniecznym warunkiem intencjonalności? Czym różni się intencjonalność angażująca pojęcia od intencjonalności niepojęciowej? W badaniach nad filozofią Kanta są to zagadnienia stosun-

${ }^{1}$ Zob. K. Twardowski, O treści i przedmiocie przedstawień, PWN, Warszawa 1965. 
kowo nowe, gdyż wcześniejszych komentatorów i krytyków filozofa bardziej interesował problem dualizmu władz poznawczych i odpowiadających im przedstawień: danych naocznych i pojęć ${ }^{2}$. Dla takich filozofów jak Salomon Maimon, Karl L. Reinhold, Johann G. Fichte, G. W. F. Hegel, problem stanowiło uzasadnienie tego dualizmu oraz możliwość powiązania różnych władz i przedstawień w procesie poznawczym.

Dwudziestowieczny polski tłumacz i interpretator Kanta, Benedykt Bornstein, podejmuje ten ostatni problem. Przytaczając argumenty Kanta za rozróżnieniem „zmysłowości” i „rozsądku”, Bornstein ukazuje racje poglądu o nie-pojęciowej naturze „oglądów”. W odróżnieniu od autorów współczesnych, Bornstein przyjmuje Kantowski non-konceptualizm i poszukuje nie tyle uzasadnienia własnego stanowiska interpretacyjnego, ile uzasadnienia stanowiska Kanta i rozwiązania problemu, do którego ono prowadzi. Moim zdaniem jednak rozważania Bornsteina warto wziąć pod uwagę także z punktu widzenia dyskusji współczesnych, które pomijają choćby metafizyczne aspekty związane $\mathrm{z}$ poruszanym zagadnieniem.

Artykuł składa się z trzech części. W części pierwszej przedstawiam wybrane stanowiska w sporze o naturę treści doświadczenia w koncepcji Kanta. Część druga dotyczy „problematu” Bornsteina oraz jego rozwiązania. Część ostatnia natomiast jest poświęcona ocenie Bornsteinowskiego rozwiązania problemu dualizmu władz poznawczych w świetle wspomnianego sporu.

\section{Czy Kant jest (non-)konceptualistą?}

Na początku postawmy dwa pytania: po pierwsze, dlaczego w debacie między konceptualizmem a non-konceptualizmem to właśnie Kant cieszy się szczególnym zainteresowaniem? Po drugie, dlaczego ta debata jest tak popularna wśród współczesnych interpretatorów Kanta? Można na te pytania odpowiedzieć, przytaczając słowa jednego z protagonistów debaty, Johna McDowella, który twierdzi, że „Kant powinien w dalszym ciągu zajmować centralne miejsce w naszej dyskusji dotyczącej sposobu, w jaki myślenie odnosi się do rzeczywistości”3. Zdaniem McDowella Kant reprezentuje sta-

${ }^{2}$ Zob. F. C. Beiser, The Fate of Reason. German Philosophy from Kant to Fichte, Harvard University Press, Cambridge MA 1987.

${ }^{3}$ J. H. McDowell, Mind and World, Harvard University Press, Cambridge MA 1996. 
nowisko konceptualistyczne, ponieważ według Kanta „wiedza empiryczna stanowi rezultat współpracy między odbiorczością a samorzutnością. [...] Odbiorczość nie dodaje do tej współpracy niczego odrębnego, nawet pojęciowo. Odpowiednie zdolności posługiwania się pojęciami (conceptual capacities) są zaangażowane w samą odbiorczość" ${ }^{4}$. W odróżnieniu od Wilfrida Sellarsa, który w dwojaki sposób ujmuje Kantowskie dane naoczne: zarówno jako przedmioty odniesienia terminów jednostkowych, wchodzących w skład sądów, jak i nieskonceptualizowane dane znajdujące się u podstaw procesu prowadzącego do powstania przekonań empirycznych i gwarantujące odniesienie tych przekonań do rzeczywistości pozaumysłowej ${ }^{5}-\mathrm{McDo}$ well twierdzi, że każdy akt spostrzeżeniowy, według Kanta, wymaga udziału pojęć, gdyż każdy taki akt stanowi odniesienie do przedmiotu' ${ }^{6}$ Tego odniesienia, które McDowell za Sellarsem określa mianem „kierownictwa (guidance) z zewnątrz", nie zagwarantują nieustrukturowane dane zmysłowe, będące skutkiem oddziaływania przedmiotów na zmysłową odbiorczość.

Jak widać, zgodnie z konceptualistyczną interpretacją McDowella (która jest dość rozpowszechniona) ${ }^{7}$, koniecznym warunkiem intencjonalności jest pojęciowość treści doświadczenia, wszystkie zatem stany umysłu, którym nie można przypisać takiej treści, należy uznać za nieintencjonalne. Do takich stanów będzie należało doznawanie wrażeń, które w terminologii Kanta oznaczają „modyfikacje” stanu podmiotu i które należy odróżnić od „percepcji przedmiotowych”. Zauważmy, że interpretacja McDowella pozostaje zgodna $\mathrm{z}$ interpretacją, której - z braku lepszego określenia - można nadać miano sensualistycznej: Kant traktuje wrażenia jako podstawowe, bezpośrednio uchwytne „dane”, dane naoczne (Anschauungen) zaś jako rezultat intelektualnej konstrucji: syntezy różnorodności danych według reguł, jakich dostarczają czyste pojęcia intelektu9 .

\footnotetext{
${ }^{4}$ Tamże, s. 9.

${ }^{5}$ Zob. W. Sellars, Science and Metaphysics. Variations on Kantian Themes, Ridgeview, Atascadero CA 1992; W. de Vries, Sellars and McDowell on the Structure of Sensory Consciousness, „Diametros” 27 (1), 2011, s. 47-63.

${ }^{6}$ Zob. J. H. McDowell, Woodbridge Lectures, „The Journal of Philosophy” 95 (9), 1998, s. $431-490$.

${ }^{7}$ Essays on Nonconceptual Content, ed. Y. H. Gunther, The MIT Press, Cambridge MA 2003, s. 1.

${ }^{8}$ Zob. KrV, A 320/B 377.

9 Zob. R. George, Kant's Sensationism, „Synthese” 47 (2), 1981, s. 229-255; K. Westphal, Contemporary Epistemology: Kant, Hegel, McDowell, „European Journal of Philosophy” 14 (2), 2006 s. 274-301.
} 
Z kolei Hannah Ginsborg, odwołując się do koncepcji wyobraźni transcendentalnej, przypisuje Kantowi konceptualizm umiarkowany. Zdaniem Ginsborg spostrzeganiu towarzyszy „świadomość normatywności”, pochodząca $z$ intelektu wyposażonego w aprioryczne kategorie. Jednak świadomość tego rodzaju „nie zakłada jakiegokolwiek wcześniejszego ujmowania pojęc'”10. W tym przypadku intelekt niejako kieruje wyobraźnią, która syntetyzuje różnorodne dane w spostrzeżenia przedmiotów, lecz która z perspektywy podmiotu działa, by posłużyć się określeniem Kanta, niejako "na ślepo"11. Interpretacja Ginsborg pozwala dostrzec, że Kantowska teoria doświadczenia dysponuje odpowiednimi środkami pozwalającymi wyjaśnić takie procesy jak nabywanie czy uczenie się pojęć przez nieposiadające ich podmioty, w szczególności dzieci.

Zwolenniczką umiarkowanie non-konceptualistycznej interpretacji jest Lucy Allais, która twierdzi, że „jedna z podstawowych myśli Kanta jest taka, iż swego rodzaju bezpośredni kontakt z przedmiotami, polegający na uobecnianiu się jednostkowych przedmiotów w świadomości, ma istotne znaczenie dla poznania"12. Propozycja Allais ukazuje ważny aspekt omawianej teorii: dane naoczne okazują się tutaj tego rodzaju składnikami treści doświadczenia, które umożliwiają odniesienie umysłu do przedmiotów jednostkowych, podczas gdy pojęcia odpowiadają za kategoryzację, przypisywanie własności tym przedmiotom oraz ujmowanie zachodzących między nimi relacji. Richard Aquila, również odczytujący Kanta w duchu non-konceptualizmu, opisuje naoczność jako podstawową formę odniesienia do przedmiotu, przed-pojęciową (pre-conceptual) intencjonalność, której struktura decyduje o ograniczeniach ludzkiej władzy poznawczej, a w konsekwencji dziedziny możliwych przedmiotów poznania ${ }^{13}$. Według Clintona Tolleya, ta podstawowa forma odniesienia do przedmiotu stanowi szczególny sposób prezentacji przedmiotów doświadczenia, dostarczając sensów pewnego rodzaju przedstawień - we Frege'owskim rozumieniu terminu „sens” ${ }^{\prime 4}$. Kantowska koncepcja naoczności zwraca uwagę na istnienie niepojęciowych sensów, które od-

${ }^{10}$ H. Ginsborg, Was Kant a nonconceptualist?, „Philosophical Studies” 137 (1), 2008, s. 65-77.

${ }^{11}$ Zob. KrV, A 78.

${ }^{12}$ L. Allais, Kant, Non-Conceptual Content and the Representation of Space, „Journal of the History of Philosophy" 47 (3), 2009, s. 392.

${ }^{13}$ R. Aquila, Representational Mind: A Study of Kant's Theory of Knowledge, Indiana University Press, Bloomington 1983.

${ }^{14}$ Zob. C. Tolley, The Non-Conceptuality of the Content of Intuitions: A New Approach, „Kantian Review" 18 (1), 2013, s. 107-136. 
powiadają temu, co Kant nazywa zjawiskiem, „nieokreślonym przedmiotem oglądania empirycznego"15.

Inni badacze podkreślają, że według Kanta naoczność to odrębne, niezależne od władzy tworzenia i stosowania pojęć, źródło pewnego rodzaju informacji. I tak, zdaniem Mario Caimi, wspomnianą zasadę, dotyczącą konieczności „współpracy” między zmysłowością a intelektem, można uznać za „rewolucyjną nowość w logice” czasów Kanta ${ }^{16}$. Treść pojęcia, zgodnie z tą zasadą, nie zależy już bowiem ,jedynie od jego logicznej możliwości” ${ }^{17}$. Z kolei Robert Hanna zwraca uwagę na fragmenty pism Kanta, w których mowa o własnościach przedmiotów niemożliwych (według Kanta) do uchwycenia za pomocą pojęć, a danych w naoczności. Chodzi tu o tzw. nieprzystające odpowiedniki - jak dwa trójkąty sferyczne leżące na różnych półkulach czy lustrzane odbicie dłoni - których opisy miałyby niczym się od siebie nie różnić, lecz które potrafimy odróżnić jakoby jedynie w naoczności. Hanna zauważa także, że niepojęciowe dane naoczne umożliwiają przed-refleksyjną, czy też proto-racjonalną, relację między ucieleśnionym (embodied) podmiotem a przedmiotami doświadczenia ${ }^{18}$.

\section{2. „Zasadniczy problemat” Benedykta Bornsteina}

Jak na tym tle przedstawiają się rozważania Bornsteina na temat Kantowskiego dualizmu władz poznawczych? Aby odpowiedzieć na to pytanie, ograniczę się do omówienia argumentów z następujących prac polskiego filozofa: Preformowana harmonia transcendentalna jako podstawa teorii poznania Kanta (1907), Zasadniczy problemat teoryi poznania Kanta (1910), Krytyka immanentna filozofii geometrji Kanta (1911) oraz Kant i Bergson. Studjum o zasadniczym problemacie teorji poznania (1913). Są to wczesne prace Bornsteina, w późniejszym okresie twórczości filozof zajął się bowiem zagadnieniami filozofii matematyki, filozofii nauki oraz próbą opracowania naukowej

\footnotetext{
${ }^{15} \mathrm{KrV}, \mathrm{A} 20 / \mathrm{B} 34$.

${ }^{16}$ M. Caimi, «Gedanken ohne Inhalt sind leer», „Kant-Studien” 96, 2005, s. 141.

17 Tamże, s. 144.

${ }^{18}$ R. Hanna, The Inner and the Outer: Kant's 'Refutation' Reconstructed, „Ratio” 13 (2), 2000: 146-174; tenże, Kant and Nonconceptual Content, „European Journal of Philosophy” 13 (2), 2005: 247-290; tenże, The Myth of the Given and the Grip of the Given, „Diametros” 27 (1), 2011: 25-46.
} 
metafizyki. Zagadnienia te oczywiście pomijam, ponieważ interesuje mnie tutaj działalność Bornsteina jako historyka filozofii i krytyka Kanta, który, jak zauważa w recenzji Zasadniczego problematu Józefa Kodisowa ${ }^{19}$ (1910), a sto lat później Krzysztof Śleziński w monografii poświęconej polskiemu tłumaczowi Prolegomenów, dostarcza przykładu „twórczego wchodzenia w dialog z myślą europejską, a nie jedynie jej kopiowania"20.

Tak zatem pierwsza praca to opublikowany w 1907 roku w „Przeglądzie Filozoficznym” doktorat Bornsteina. Dotyczy on projektu filozofii transcendentalnej znanego z głównego dzieła Kanta, Krytyki czystego rozumu. Projekt ten, mający na celu znalezienie odpowiedzi na pytanie, jak możliwa jest zgodność apriorycznych struktur umysłu z koniecznymi właściwościami przedmiotów poznania, jest skazany, zdaniem Bornsteina, na niepowodzenie, ponieważ opiera się na założeniu, którego prawdziwości nie sposób wykazać na gruncie filozofii krytycznej. Założenie to mówi o konieczności powiązania przedstawień rozsądku (pojęć) i zmysłowości (oglądów) w doświadczeniu. Nie sposób wykazać możliwości tego powiązania, ponieważ są to przedstawienia różnego rodzaju (pojęcia są ogólne i dyskursywne, oglądy - jednostkowe), a poza tym nie rozumiemy „związku kategorji z oglądami, albowiem kategorje są, według poglądów Kanta, niezależne od oglądów, a oglądy od kategorji”21. Tego „problematu”, według Bornsteina, nie rozwiązuje ani transcendentalna dedukcja kategorii, ani koncepcja wyobraźni transcendentalnej jako łącznika między zmysłowością a rozsądkiem, ani transcendentalny schematyzm traktujący o przedstawieniach pośredniczących między kategoriami a formami zmysłowego oglądu. Jest tak dlatego, że wszystkie te koncepcje w istocie zakładają to, co należałoby udowodnić, czyli możliwość powiązania heterogenicznych przedstawień. Jak więc czytamy w Preformowanej harmonii transcendentalnej:

żaden dowód nie wykaże możliwości związku odrębnych a niezależnych od siebie pierwiastków, jeżeli warunku tego związku nie będzie szukał w naturze samych tych pierwiastków, w ich zgodności wzajemnej, harmonji. Jako conditio sine qua non możliwości połączenia zmysłowości i rozsądku w poznaniu

\footnotetext{
${ }^{19}$ J. Kodisowa, B. Bornstein. Zasadniczy problemat teoryi poznania Kanta, „Przegląd Filozoficzny" 13, 1910: 343-347.

${ }^{20}$ K. Śleziński, Filozofia Benedykta Bornsteina oraz wybór i opracowanie niepublikowanych pism, Uniwersytet Śląski w Katowicach, Wydawnictwo «scriptum», Katowice 2011, s. 19.

${ }^{21}$ B. Bornstein, Preformowana harmonia transcendentalna jako podstawa teorii poznania Kanta, „Przegląd Filozoficzny” 10, 1907, s. 277.
} 
przedmiotowym przyjąć trzeba, wychodząc z założeń, harmonję między elementami tego poznania ${ }^{22}$.

Tak więc „problemat” Kanta znajdzie rozwiązanie, jeśli założymy istnienie harmonii transcendentalnej między dwiema różnymi władzami poznawczymi i właściwymi im, wzajemnie od siebie odmiennymi, rodzajami przedstawień. Ponieważ nie można dostarczyć immanentnego wyjaśnienia tej harmonii, trzeba, jak mówi Bornstein, przyjąć wyjaśnienie transcendentne i uznać, że jej podstawą jest Bóg. Autor twierdzi, że w Krytyce czystego rozumu Kant omija wspomniany problem, i tylko w liście do Herza z 26 maja 1789 roku oraz w polemicznym piśmie przeciw Eberhardowi z 1790 roku (O odkryciu, po którym wszelka nowa krytyka czystego rozumu jest zbędna ze względu na istnienie wcześniejszej) wzmiankuje o harmonii między władzami poznawczymi. Nie ulega jednak wątpliwości, że proponowane rozwiązanie zbliża teorię Kanta do teorii Leibniza, a gdyby usunąć z niej to, co Bornstein nazywa „zasadą kopernikańską" ${ }^{23}$, także - zdaniem autora Preformowanej harmonii do preformizmu.

Opublikowana trzy lata później, nakładem Księgarni Centnerszwera w Warszawie i Altenberga we Lwowie, rozprawa Zasadniczy problemat teoryi poznania Kanta rozwija wątki obecne w pracy doktorskiej Bornsteina. I tak, Bornstein podkreśla różnicę co do struktury między oglądami a pojęciami („oglądy zawierają swe części składowe w sobie, pojęcia, jak gdyby, pod sobą"24), którą to strukturę niekiedy charakteryzuje się, odpowiednio, jako mereologiczną i teoriomnogościową ${ }^{25}$. Zauważa także, że realne przeciwieństwo między zmysłowością a rozsądkiem dotyczy sposobu ich odniesienia do przedmiotu - ma zatem charakter psychologiczny, a nie jedynie logiczny - i wyróżnia dwa etapy procesu poznawczego: pierwszy, w którym dane są „nieokreślone jeszcze oglądy” i drugi, w którym dane są „objekty”26. „Oglądy” można określić jako dane zmysłowe, „objekty” - jako dane świado-

\footnotetext{
22 Tamże, s. 293.

23 Tamże, s. 299.

${ }^{24}$ B. Bornstein, Zasadniczy problemat teoryi poznania Kanta, skład główny w Księgarni

G. Centnerszwera i Ski w Warszawie oraz H. Altenberga we Lwowie 1910, s. 14.

${ }^{25}$ K. D. Wilson, Kant on Intuition, „Philosophical Quarterly 25 (100), 1975, s. 247-265.

${ }^{26}$ B. Bornstein, Zasadniczy problemat..., s. 52.
} 
mości ${ }^{27}$. Co ważne, Bornstein wykazuje, wbrew dość powszechnej opiniii ${ }^{28}$, że Kant dysponuje odpowiednimi „motywami” rozróżnienia władz poznawczych i ich przedstawień. Motywy te Bornstein dzieli na moralno-religijne i teoretyczne. Należą do nich:

(a) umieszczenie Boga poza czasem i przestrzenią;

(b) deprecjacja roli zmysłów w procesie poznawczym;

(c) „ustanowienie państwa rzeczy samych w sobie, działających na nasz podmiot"29;

(d) etyczny intelektualizm, zgodnie z którym praktyczne poznanie noumenów (Bóg, wolność) wymaga oddzielenia wyższych władz poznawczych (intelekt, rozum) od zmysłowości;

(e) możliwość czynienia z rozumu czysto logicznego użytku;

(f) uznanie, że treść poznania znajduje źródło w zmysłowości;

(g) doświadczenie wewnętrzne, pouczające o biernym charakterze zmysłowości;

(h) teoria matematyki jako nauki apodyktycznie pewnej oraz sądów matematycznych jako syntetycznych a priori;

(i) problemy metafizyki klasycznej: amfibolie i antynomie czystego rozumu.

Tak więc wbrew neokantystom Bornstein utrzymuje, iż „nie ulega najmniejszej wątpliwości, że przeciwstawność zmysłowości i rozsądku nie była dla Kanta twierdzeniem dogmatycznem, przyjętem bez dowodów i nieuzasadnionem, lecz artykułem, znajdującym liczne potwierdzenia, wytrzymującym próby krzyżowe (antynomij i amfibolij) i mogącym być bezpośrednio sprawdzonym i dowiedzionym (przez zmysł wewnętrzny)" ${ }^{30}$.

Dalsze rozważania, w cz. II i III Zasadniczego problematu, dotyczą wspomnianej już krytyki dedukcji transcendentalnej i schematyzmu oraz metafizycznego rozwiązania „problematu”, który miał zaprowadzić Kanta do postulowania „prestabilitowanej harmonii transcendentalnej” - ujawnionej za sprawą krytyki Maimona (w liście z 7 kwietnia 1789 roku) jakoby „rze-

\footnotetext{
${ }^{27}$ Por. tamże, s. 56.

${ }^{28}$ Zob. H. Vaihinger, Kommentar zu Kants Kritik der reinen Vernunft, Union Deutsche Verlagsgesellschaft, Stuttgart 1922; L. Falkenstein, Kant's Intuitionism. A Commentary on the Transcendental Aesthetic, University of Toronto Press, Toronto 2004, s. 29; P. Spryszak, Kilka uwag na temat estetyki transcendentalnej Kanta, [w:] Kant wobec problemów wspótczesnego świata, red. J. Miklaszewska, P. Spryszak, Wyd. Uniwersytetu Jagiellońskiego, Kraków 2006, s. 324n.

${ }^{29}$ B. Bornstein, Zasadniczy problemat..., s. 73.

${ }^{30}$ Tamże, s. 89-91.
} 
czywistej podstawy" teoretycznej filozofii Kanta ${ }^{31}$. Ponieważ zagadnienia te poruszałam przy okazji omawiania poprzedniego tekstu Bornsteina, przejdę do kolejnych prac.

W zamieszczonym w „Przeglądzie Filozoficznym” z 1911 roku artykule Krytyka immanentna filozofji gieometrji Kanta Bornstein wskazuje na niekonsekwencje Kantowskiej teorii geometrii, a zwłaszcza na obecność czynników empirycznych w kształtowaniu i uzasadnianiu sądów tej nauki. Według Bornsteina Kant operuje ważnym, lecz nieuzasadnionym założeniem, że przestrzeń geometrii Euklidesowej jest identyczna z przestrzenią naszego doświadczenia ${ }^{32}$, problematycznym tym bardziej, że ta ostatnia zależy od rzeczy samych w sobie, których własności ani sposobu działania nie jesteśmy w stanie poznać. Inny przykład niekonsekwencji Kanta stanowi „paradoks figur symetrycznych"33, który pokazuje, że „głoszona przez Kanta racjonalność gieometrji stoi w sprzeczności z nauką jego o niepojęciowej naturze przestrzeni”"34. Oglądy, którym nie towarzyszą żadne pojęcia, Kant uznaje za „ślepe”35, czyli poznawczo bezwartościowe, geometria zaś poucza nas o zjawiskach, których nie możemy poznać za pomocą pojęć, a które mogą być dane jedynie w naoczności, jej dane okazują się zatem pozbawione wartości poznawczej.

O „faktach irracjonalnych”36, do których zalicza się wspomniany paradoks, pisze Bornstein także w rozprawie Kant i Bergson. Studjum o zasadniczym problemacie teorji poznania, wydanej w Księgarni Wendego („Drukarnia Polska”) w Warszawie w 1913 roku. Możliwość tych faktów ma według Kanta dowodzić, że „przestrzeń nasza jest czymś wybitnie niepojęciowym, czymś, co zawiera w sobie pierwiastek specyficzny, niepoddający się zupełnie ujęciu przez myśl dyskursywną" ${ }^{37}$. Jednak, jak zauważa autor rozprawy, figury symetryczne można pojęciowo w prosty sposób odróżnić, przypisując im odpowiednie współrzędne w przestrzeni: na przykład, wierzchołek figury

\footnotetext{
31 Tamże, s. 223.

${ }^{32}$ B. Bornstein, Krytyka immanentna filozofji gieometrji Kanta, „Przegląd Filozoficzny” 14, 1911, s. 322, P. Kitcher, Kant's Transcendental Psychology, Oxford University Press, Oxford/ New York 1990.

${ }^{33}$ B. Bornstein, Krytyka immanentna filozofi gieometrji Kanta, s. 325.

${ }^{34}$ Tamże.

${ }^{35}$ zob. KrV, A 51/B 75.

${ }^{36}$ B. Bornstein, Kant i Bergson. Studjum o zasadniczym problemacie teorji poznania, księgarnia Wendego i Ski, Warszawa 1913, s. 13.

37 Tamże, s. 14.
} 
A położonej na górnej półkuli sfery opiszemy za pomocą współrzędnych $<$, $y, z>$, a wierzchołek figury A' położonej na dolnej półkuli sfery - za pomocą współrzędnych $<\mathrm{x}, \mathrm{y},-\mathrm{z}>^{38}$. A zatem $\mathrm{z}$ różnicy między dziedziną zmysłowości i rozsądku nie musi wynikać niemożliwość pojęciowego ujęcia przedmiotów naoczności, ani też błędność ujęcia tego, co jednostkowe, w poznaniu operującym pojęciami ${ }^{39}$. Z tej perspektywy tzw. argument $\mathrm{z}$ bogactwa treści doświadczenia percepcyjnego (richness argument), do którego odwołują się zwolennicy non-konceptualizmu ${ }^{40}$, traci swoją moc, treść ta bowiem, według Bornsteina, może zostać przynajmniej potencjalnie skonceptualizowana. Nazwy deskrypcyjne, jak <dom znajdujący się w 1912 roku w Warszawie przy ul. Włodzimierskiej, oznaczony nr. 8>, umożliwiają identyfikację przedmiotów jednostkowych, choć treść takiej nazwy nie musi (a nawet nie może) być identyczna $z$ treścią spostrzeżenia jednostkowego przedmiotu.

Zdaniem Bornsteina Kant uznaje, iż za pomocą pojęć nie można adekwatnie oddać własności przedmiotu danego w naoczności, tylko dlatego, że przyjmuje błędną racjonalistyczną zasadę, zgodnie z którą przedmiot poznania miałby posiadać taką samą naturę jak treść poznania, ta zaś jest pojęciowa. Zgodnie z tą interpretacją, to, co Bornstein określa mianem elementu wyobrażeniowego, nie wchodzi według Kanta w skład treści poznania, a dopiero takie połączenie wyobrażenia i pojęcia pozwoliłoby na adekwatne ujęcie "przedmiotu wyobrażeniowego", czy też przedmiotu jednostkowego, w poznaniu ${ }^{41}$. Na podstawie tych rozważań można dojść do wniosku, że $\mathrm{w}$ interpretacji Bornsteina nie może być miejsca na niepojęciową treść doświadczenia w Kantowskiej koncepcji poznania empirycznego.

\section{Bornstein, Kant i (non-)konceptualizm}

W kontekście sporu o naturę treści doświadczenia dwa pytania w związku z interpretacją Bornsteina wydają się ważne: (1) Czy problem możliwości

\footnotetext{
${ }^{38}$ Por. tamże, s. 39n.

${ }^{39}$ Por. tamże, s. 53.

${ }^{40}$ R. G. Heck, Nonconceptual Content and the 'Space of Reasons', „The Philosophical Review” 109 (4), 2000, s. 483-523; M. Tye, Nonconceptual Content, Richness, and Fineness of Grain, [in:] Perceptual Experience, eds. T. Gendler, J. Hawthorne, Oxford University Press, Oxford, New York 2005, s. 504-530.

${ }^{41}$ B. Bornstein, Kant i Bergson..., s. 63.
} 
„współpracy” między władzami poznawczymi jest rzeczywiście istotny, a jeśli tak, to czy rozwiązuje go koncepcja harmonii transcendentalnej? (2) Czy rzeczywiście Kant nie odróżnia między treścią a przedmiotem przedstawienia?

Zacznę od pytania drugiego. Istotnie, odpowiedź na nie nie wydaje się zbyt prosta i z pewnością wymagałaby analizy takich terminów, jak: przedstawienie (Vorstellung), przedmiot (Gegenstand, Objekt), zjawisko (Erscheinung), które trudno uznać za jednoznaczne. Należałoby także określić, co u Kanta miałoby odpowiadać triadzie "akt, treść, przedmiot”, opisującej proces poznawczy. Czy byłaby to triada „przedstawienie, zjawisko, rzecz sama w sobie”, czy może raczej „przedstawienie-akt, przedstawienie-treść, zjawisko-przedmiot"?

Niezależnie od tego, jak odpowiemy na te pytania, moim zdaniem można zasadnie mówić o trójelementowej strukturze procesu poznawczego według Kanta. Po pierwsze, gdyby Kant nie odróżniał między treścią a przedmiotem przedstawienia, nie czyniłby rozróżnienia między danymi naocznymi (Anschauungen, intuitus) a wrażeniami (Empfindungen, sensationes), z których pierwsze uznaje za percepcje obiektywne, drugie zaś za subiektywne ${ }^{42}$. Gdyby Kantowski model procesu poznawczego składał się tylko z czynności i przedmiotu poznania, dane naoczne nie różniłyby się od wrażeń, jedne i drugie bowiem rozpatrywane jako czynności (czy może raczej - stany) zmysłowości charakteryzują się biernością, a więc zależą one od „pobudzeń”, oddziaływań nieznanego nam przedmiotu (bądź przedmiotów) na nasz umysł. Stany te można jednak od siebie odróżnić wskazując na ich odmienne sposoby odniesienia do przedmiotu, czyli treść (ściślej mówiąc, w przypadku wrażeń takie odniesienie nie zachodzi; są one nieintencjonalnymi stanami umysłu).

Po drugie, właśnie ze względu na odmienny sposób przedstawiania przedmiotu odróżnia Kant dane naoczne od pojęć: pierwsze przedstawiają przedmiot bezpośrednio, drugie natomiast - za pośrednictwem cechy, która może być wspólna wielu przedmiotom ${ }^{43}$. Nie jest więc tak, że za odniesienie danych naocznych do przedmiotów odpowiadają jedynie pojęcia, ponieważ pojęcia $\mathrm{z}$ definicji nie odnoszą się do przedmiotów bezpośrednio. Dzięki danym naocznym przedmiot jest dany, dzięki pojęciom - ujęty jako przedmiot myśli, przy czym pierwszy sposób przedstawiania przedmiotu nie zakłada aktywności poznawczej w postaci syntezy, wiązania różnorodnych danych czy

\footnotetext{
${ }^{42}$ Zob. KrV, A 320/B 376-377.

${ }^{43}$ Zob. tamże.
} 
przedstawień: to, co tę aktywność zakłada, to przedstawienie przedmiotu za pomocą sądu, czyli poznanie.

Po trzecie, to dzięki połączeniu pojęć i danych naocznych może dopiero dojść do poznania przedmiotu. Zgodnie ze słynną tezą Kanta: „Myśli bez treści naocznej (Inhalt) są puste, dane naoczne bez pojęć ślepe" ${ }^{34}$, treści danemu pojęciu dostarcza powiązana $\mathrm{z}$ nim dana naoczna. Nie jest wobec tego prawdą, że poznanie według Kanta zachodzi tylko i wyłącznie w „elemencie pojęciowym" ${ }^{35}$. Co więcej, przytoczona teza Kanta sugeruje, że treść pojęć nie jest dla niego tym samym, co treść pojęciowa: tę ostatnią można przypisać wszelkiego rodzaju sądom, o treści pojęć natomiast można mówić wówczas, gdy dane są pojęcia lub sądy, dla których istnieje „korespondujący z owymi pojęciami ogląd”"46. Można zatem powiedzieć, że poznawczo wartościowe pojęcie ma strukturę dwuwarstwową. W rozdziale Krytyki czystego rozumu o fenomenach i noumenach Kant charakteryzuje ją w następujący sposób: „Dla każdego pojęcia potrzeba po pierwsze logicznej formy pojęcia (myślenia) w ogóle, a po wtóre także możliwości tego, by dany był dla niego przedmiot, do którego by się ono odnosiło. Bez przedmiotu nie ma ono sensu i jest w swej treści zupełnie puste, choćby nawet wciąż jeszcze zawierało funkcję logiczną tworzenia pojęcia z pewnych danych (datis). Otóż przedmiot nie może być dla pojęcia dany inaczej niż w naoczności..." ${ }^{47}$. Widać stąd, że dokonana przez Bornsteina w eseju Kant i Bergson analiza koncepcji poznania według Kanta pozostaje nie do końca trafna.

Przejdę na zakończenie do pierwszego pytania postawionego na początku tej części. Do problemu możliwości powiązania danych zmysłowości i pojęć współcześni komentatorzy Kanta, których poglądy przedstawiłam w pierwszej części referatu, zdają się nie przywiązywać większej wagi. Podobni są w tym do psychologów poznawczych, którzy analizując odmienne, lecz powiązane ze sobą w poznaniu procesy spostrzegania i myślenia, opisują, jak to powiązanie zachodzi, ale nie pytają o jego warunki możliwości. Z punktu widzenia Kanta, według mnie, można podejść do tego problemu przynajmniej na dwa sposoby.

\footnotetext{
${ }^{44} \mathrm{KrV}$, A 51 / B 75.

${ }^{45}$ B. Bornstein, Kant i Bergson..., s. 59.

${ }^{46}$ I. Kant, O odkryciu, po którym wszelka nowa krytyka czystego rozumu jest zbędna ze względu na istnienie wcześniejszej $i$ inne rozprawy filozoficzne, przeł. Translatorium Filozofii Niemieckiej Instytutu Filozofii UMK, Toruń 2009, s. 80.

${ }^{47} \mathrm{KrV}, \mathrm{A} 239$ / B 298.
} 
Po pierwsze, można uznać ten problem za nierozwiązywalny w ramach filozofii krytycznej, odrzucając jednak propozycję Bornsteina, który wskazuje na metafizykę Leibniza jako dopełnienie tej filozofii. W liście do Herza z 26 maja 1789 roku Kant przyznaje, że nie da się wyjaśnić możliwości form naoczności i kategorii, którymi dysponuje intelekt podmiotu poznającego, ponieważ takie wyjaśnienie wymagałoby, abyśmy posiadali poznanie intelektu innego niż nasz, który moglibyśmy porównać z naszym intelektem. Kant odrzuca jednak możliwość poznania intelektu intuitywnego, który przypisuje istocie Boskiej, i podkreśla dyskursywność wyższej władzy poznawczej człowieka. Twierdzenie, że gwarantem „współpracy” między zmysłowością a rozsądkiem miałby być Bóg - wobec niemożności znalezienia takiego gwaranta w sferze dostępnej poznawczo - nie tylko, co oczywiste, przekracza wyznaczone przez Kanta granice możliwego poznania, ale także koliduje z głoszonym przez niego poglądem, zgodnie z którym „Krytyka nie dopuszcza bynajmniej żadnych stworzonych [pierwotnych] lub wrodzonych przedstawień; bez względu na to, czy należą one do oglądu, czy są pojęciami intelektu, uznaje je ona za nabyte" ${ }^{\# 8}$. Zdolność wiązania pojęć z danymi zmysłowości trzeba zatem przypisać wyłącznie umysłowi podmiotu, a nie sprowadzać do Boskiej decyzji o ustanowieniu harmonii umożliwiającej takie powiązanie ${ }^{49}$.

Po drugie, problem sformułowany przez Bornsteina, a wcześniej także na przykład przez Maimona, można potraktować jako przypadek ogólniejszego zagadnienia, mianowicie możliwości relacji między odrębnymi przedmiotami. Zagadnienie to pojawia się u Kanta w pismach przedkrytycznych. Na przykład, w rozprawie z 1755 roku, Nowe wyjaśnienie pierwszych zasad poznania metafizycznego, Kant porusza problem relacji przestrzennych między niezależnymi od siebie substancjami. Według Kanta z samego istnienia substancji nie wynika zachodzenie między nimi jakichkolwiek relacji, w tym relacji przestrzennych. Podstawa tych relacji znajduje się raczej na zewnątrz substancji, w Boskim umyśle ( $\mathrm{tj}$. $\mathrm{w}$ Boskim intelekcie lub woli ${ }^{50}$ ). Można powiedzieć, że w okresie krytycznym umysł Boski zostaje zastąpiony przez umysł ludzki, który staje się autorem wszelkiego rodzaju powiązań. W szcze-

\footnotetext{
${ }^{48}$ I. Kant, O odkryciu, po którym wszelka nowa krytyka czystego rozumu jest zbędna..., s. 76.

${ }^{49}$ Por. W. Heflik, Kants Theorie der Affinität und das Prinzip der prästabilierten Harmonie, [w:] S. Bacin, A. Ferrarin, C. La Rocca, M. Ruffing (red.), Kant und die Philosophie in weltbürgerlicher Absicht. Akten des XI. Internationalen Kant-Kongresses, De Gruyter, Berlin/Boston 2013, s. 355.

${ }^{50}$ Por. Ch. Insole, Intellectualism, Relational Properties and the Divine Mind in Kant's PreCritical Philosophy, „Kantian Review”, 16 (3), 2011, s. 399-427.
} 
gólności, źródłem powiązania przedmiotów relacjami przestrzennymi stają się tkwiące $\mathrm{w}$ tym umyśle formy zmysłowej naoczności. Wracamy więc do wcześniejszego wniosku, który siłą rzeczy nie usatysfakcjonuje ani metafizycznie, ani redukcjonistycznie zorientowanego interpretatora Kanta: podstawą poszukiwanej „harmonii” musi być ludzki umysł, z tym że - co stawia pod znakiem zapytania „krytyczność” projektu Kanta - należy uznać, że podstawy tej nie jesteśmy w stanie do końca zrozumieć.

\section{Bibliografia}

Dzieła Immanuela Kanta

Akademieausgabe von Immanuel Kants Gesammelten Werken, B. IX (Briefwechsel 1789-1794), wydanie internetowe: http://www.korpora.org/kant/verzeichnisse-gesamt.html.

Dzieła zebrane, t. 1: Pisma przedkrytyczne, przeł. Translatorium Filozofii Niemieckiej Instytutu Filozofii UMK, Toruń 2010.

Krytyka czystego rozumu, przeł. R. Ingarden, Wyd. Antyk, Kęty 2001.

O odkryciu, po którym wszelka nowa krytyka czystego rozumu jest zbędna ze względu na istnienie wcześniejszej i inne rozprawy filozoficzne, przeł. Translatorium Filozofii Niemieckiej Instytutu Filozofii UMK, Toruń 2009.

Inne dzieła, opracowania i komentarze

Allais L., Kant, Non-Conceptual Content and the Representation of Space, "Journal of the History of Philosophy" 47 (3), 2009, s. 383-413.

Aquila R., Representational Mind: A Study of Kant's Theory of Knowledge, Indiana University Press, Bloomington 1983.

Beiser F. C., The Fate of Reason. German Philosophy from Kant to Fichte, Harvard University Press, Cambridge MA 1987.

Bornstein B., Preformowana harmonia transcendentalna jako podstawa teorii poznania Kanta, „Przegląd Filozoficzny” 10, 1907, s. 261-303.

Bornstein B., Zasadniczy problemat teoryi poznania Kanta, skład główny w Księgarni G. Centnerszwera i Ski w Warszawie oraz H. Altenberga we Lwowie.

Bornstein B., Krytyka immanentna filozofji gieometrji Kanta, „Przegląd Filozoficzny” 14, 1911, s. 317-328.

Bornstein B., Kant i Bergson. Studjum o zasadniczym problemacie teorji poznania, księgarnia Wendego i Ski, Warszawa 1913.

Caimi M., "Gedanken ohne Inhalt sind leer», „Kant-Studien” 96, 2005, s. 135-146. 
Falkenstein L., Kant's Intuitionism. A Commentary on the Transcendental Aesthetic, University of Toronto Press, Toronto 2004.

George R., Kant's Sensationism, „Synthese” 47 (2), 1981, s. 229-255.

Ginsborg H., Was Kant a nonconceptualist?, „Philosophical Studies” 137 (1), 2008, s. $65-77$.

Gunther Y. H. (ed.), Essays on Nonconceptual Content, The MIT Press, Cambridge MA 2003.

Hanna R., The Inner and the Outer: Kant's 'Refutation' Reconstructed, „Ratio” 13 (2), 2000, s. 146-174.

Hanna R., Kant and Nonconceptual Content, „European Journal of Philosophy” 13 (2), 2005, s. 247-290.

Hanna R., The Myth of the Given and the Grip of the Given, „Diametros” 27 (1), 2011, s. $25-46$.

Heck R. G., Nonconceptual Content and the 'Space of Reasons', „The Philosophical Review" 109 (4), 2000, s. 483-523.

Heflik W., Kants Theorie der Affinität und das Prinzip der prästabilierten Harmonie, [w:] S. Bacin, A. Ferrarin, C. La Rocca, M. Ruffing (red.), Kant und die Philosophie in weltbürgerlicher Absicht. Akten des XI. Internationalen Kant-Kongresses, De Gruyter, Berlin/Boston 2013, s. 347-358.

Insole Ch., Intellectualism, Relational Properties and the Divine Mind in Kant's PreCritical Philosophy, „Kantian Review” 16 (3), 2011, s. 399-427.

Kitcher P., Kant's Transcendental Psychology, Oxford University Press, Oxford/New York 1990.

Kodisowa J., B. Bornstein, Zasadniczy problemat teoryi poznania Kanta, „Przegląd Filozoficzny" 13, 1910, s. 343-347.

McDowell J. H., Mind and World, Harvard University Press, Cambridge MA 1996.

McDowell J. H., Woodbridge Lectures, „The Journal of Philosophy” 95 (9), 1998 431-490.

Sellars W., Science and Metaphysics. Variations on Kantian Themes, Ridgeview, Atascadero CA 1992.

Spryszak P., Kilka uwag na temat estetyki transcendentalnej Kanta, [w:] J. Miklaszewska, P. Spryszak (red.), Kant wobec problemów współczesnego świata, Wydawnictwo Uniwersytetu Jagiellońskiego, Kraków 2006: 323-330.

Śleziński K., Filozofia Benedykta Bornsteina oraz wybór i opracowanie niepublikowanych pism, Uniwersytet Śląski w Katowicach, Wydawnictwo «scriptum», Katowice 2011.

Tolley C., The Non-Conceptuality of the Content of Intuitions: A New Approach, „Kantian Review" 18 (1), 2013: 107-136.

Tye M., Nonconceptual Content, Richness, and Fineness of Grain, [in:] T. Gendler, J. Hawthorne (eds.), Perceptual Experience, Oxford University Press, Oxford, New York 2005: 504-530. 
Twardowski K., O treści i przedmiocie przedstawień, PWN, Warszawa 1965.

Vaihinger H., Kommentar zu Kants Kritik der reinen Vernunft, Union Deutsche Verlagsgesellschaft, Stuttgart 1922.

Vries de W., Sellars and McDowell on the Structure of Sensory Consciousness, „Diametros" 27 (1), 2011: 47-63.

Westphal K., Contemporary Epistemology: Kant, Hegel, McDowell, „European Journal of Philosophy" 14 (2), 2006: 274-301.

Wilson K. D., Kant on Intuition, „Philosophical Quarterly 25 (100), 1975: 247-265.

\section{Abstract \\ Intuition in Kant's Philosophy According to Benedykt Bornstein}

The article presents the views of Benedict Bornstein, formulated in his early writings, such as The Pre-established Transcendental Harmony as the Foundation of Kant's Theory and The Basic Problem of Kant's Theory of Cognition (both works originally written in Polish). These views pertain to the Kantian dualism of concepts and intuitions and they are presented against the background of the contemporary debate about the contents of perceptual experience. Recognizing the rightness of Bornstein's claim about the non-conceptual character of the Kantian intuitions, I criticize Bornstein's solution to the problem of dualism, which necessitates an appeal to the conception of transcendental harmony, established by an act of God's will.

Key words: Kant, dualism of concepts and intuitions, Benedict Bornstein, transcendental harmony, non-conceptual content 